\title{
Phenolics from Rhagadiolus stellatus (Asteraceae, Cichorieae)
}

\author{
Romana KrIMPLSTÄTTER ${ }^{1}$, Benjamin MA ${ }^{1}$, Renate SPITALER ${ }^{2}$, \\ Ernst ELLMERER ${ }^{3}$, Christian ZIDORN * 1
}

${ }_{1}^{1}$ Institut für Pharmazie, Universität Innsbruck, Josef-Moeller-Haus, Innrain 52, A-6020 Innsbruck, Austria.

2 Institut für Lebensmitteluntersuchung Innsbruck, Österreichische Agentur für Gesundheit und Ernährungssicherheit, Technikerstraße 70, A-6020 Innsbruck, Austria.

${ }^{3}$ Institut für Organische Chemie, Universität Innsbruck, Innrain 52a, A-6020 Innsbruck, Austria.

* Corresponding author. E-mail: Christian.H.Zidorn@uibk.ac.at (C. Zidorn)

Sci Pharm. 2011; 79: 175-179

Published: $\quad$ February $7^{\text {th }} 2011$

Accepted: $\quad$ February $3^{\text {rd }} 2011$ doi:10.3797/scipharm.1011-12

Received: $\quad$ November $30^{\text {th }} 2010$

This article is available from: http://dx.doi.org/10.3797/scipharm.1011-12

(C) Krimplstätter et al.; licensee Österreichische Apotheker-Verlagsgesellschaft m. b. H., Vienna, Austria.

This is an Open Access article distributed under the terms of the Creative Commons Attribution License (http://creativecommons.org/licenses/by/3.0/), which permits unrestricted use, distribution, and reproduction in any medium, provided the original work is properly cited.

\begin{abstract}
Rhagadiolus stellatus Gaertn., a Mediterranean member of the Cichorieae tribe of the Asteraceae family used as a food plant, was analyzed for its spectrum of phenolic compounds. Kaempferol 3-O- $\beta$-glucoside 1, kaempferol 3-O- $\beta$ rutinoside (nicotiflorin) 2, quercetin $3-O-\beta$-glucoside 3 , and luteolin 4 were isolated from the $n$-butanol layer of a methanolic extract of whole plants of $R h$. stellatus of Spanish origin by repeated Sephadex LH-20 column chromatography. Structures were determined based on NMR and MS data as well as by comparison with literature data. Additionally, chlorogenic acid $\mathbf{5}$ and 3,5-dicaffeoylquinic acid 6 were detected by HPLC/DAD and HPLC/MS. Chemosystematic implications of the presented findings are discussed in comparison with other members of the Cichorieae tribe.
\end{abstract}

\section{Keywords}

Rhagadiolus stellatus Gaertn. $\cdot$ Asteraceae $・$ Cichorieae $•$ Flavonoids $\bullet$ Chemosystematics

\section{Introduction}

Rhagadiolus stellatus (L.) Gaertn. is one of two species of the genus Rhagadiolus. According to recent molecular studies Rhagadiolus is closest related to the genus Lapsana and both genera cluster within the genus Crepis s.l. [1]. Rhagadiolus stellatus is a herb of up to $50 \mathrm{~cm}$ height, with small flowering heads composed of yellow ligulate flowers. The 
achenes are narrowly cylindrical and bear no pappus. The outer achenes are longpersistent and form a characteristic radiating infructescence, as also indicated in the specific epithet. The natural distribution area of $R h$. stellatus encompasses Southern Europe, Northern Africa, the Macaronesian Archipelago, and the West and Southwest of Asia [2,3]. In the only phytochemical investigation of $R h$. stellatus so far, quercetin was found to be the major aglycon in leaves after hydrolysis of the genuine flavonoids [4].

\section{Results and Discussion}

Flavonoids (Fig. 1) kaempferol 3-O- $\beta$-glucoside 1, kaempferol 3-O- $\beta$-rutinoside (nicotiflorin) 2, quercetin 3-O- $\beta$-glucoside 3, and luteolin 4 were identified based on NMR and MS data as well as by comparison with literature data of the above and related compounds [5-12]. Phenolic acids chlorogenic acid 5 and 3,5-dicaffeoylquinic acid 6 (Fig. 1) were detected by HPLC/DAD and HPLC/MS in comparison with authentic reference compounds using an established system [13].<smiles>[R]c1cc(-c2oc3cc(O)cc(O)c3c(=O)c2[R])ccc1O</smiles>

$$
\begin{array}{ll}
\text { 1: } & \mathrm{R}^{1}=\beta \text {-glucopyranosyl, } \mathrm{R}^{2}=\mathrm{H} \\
\text { 2: } & \mathrm{R}^{1}=\beta \text {-rutinosyl, } \mathrm{R}^{2}=\mathrm{H} \\
\text { 3: } & \mathrm{R}^{1}=\beta \text {-glucopyranosyl, } \mathrm{R}^{2}=\mathrm{OH}
\end{array}
$$<smiles>O=c1cc(-c2ccc(O)c(O)c2)oc2cc(O)cc(O)c12</smiles><smiles>[R]C=[R]C=[R]</smiles>

Fig. 1. Structures of phenolics isolated from and detected in Rhagadiolus stellatus.

Chlorogenic acid 5 and 3,5-dicaffeoylquinic acid 6 occur ubiquitously in the Asteraceae. Luteolin $\mathbf{4}$ is a very common flavonoid in the Cichorieae and has also been reported from both Crepis and Lapsana, which are closely related to Rhagadiolus [1, 14]. Quercetin 3-Oglucoside 3 was also reported from aerial parts of Lapsana communis L. but has not yet been found in Crepis [14]. In contrast, kaempferol 3-O-derivatives 1 and 2 are rather rare flavonoids in the Cichorieae tribe. Kaempferol 3-O- $\beta$-glucoside 1 has only been reported from the genus Cichorium (detected in leaves of four species), aerial parts of Lactuca tatarica C.A.Mey., and in whole plants of five species of Stephanomeria. Kaempferol 3-O$\beta$-rutinoside 2 has only been reported from aerial parts of Pinaropappus roseus Less. and Scolymus hispanicus L. [14].

A deeper chemosystematic interpretation of the above findings is difficult because of the poor or missing phytochemical data for most of the related genera. Phenolics of many 
species of Crepis were reported recently but these data are of limited value in the present context because this study was focused on flowering heads, only [15]. Nonetheless, the data presented here suggest that Rhagadiolus is not only morphologically but also chemically (prevalence of flavonols) differentiated from the genus Crepis (prevalence of flavones) and thus the decision of Enke and Gemeinholzer [1] to keep Rhagadiolus as a genus separate from Crepis is compatible with the available phytochemical data.

\section{Experimental}

\section{Plant material}

Rh. stellatus was collected in April 2009 between Vélez Rubio and Santa Maria de Nieva/Almeria/Andalucia/Spain; N 37³7'26"; W 0200'53"; alt.: $890 \mathrm{~m}$. Voucher specimens are deposited in the herbarium of the Institut für Botanik, Universität Innsbruck, Austria (voucher codes: IB-33270) and in the private herbarium of CZ (CZ-20090417A-2).

\section{Natural product isolation and identification}

Air-dried, ground whole plants $(719 \mathrm{~g})$ of $R h$. stellatus were exhaustively macerated with $\mathrm{MeOH}$ to yield $101 \mathrm{~g}$ of crude extract after evaporation of the solvent in vacuo. The crude extract was re-dissolved in a mixture of $\mathrm{MeOH}$ and $\mathrm{H}_{2} \mathrm{O}(1 / 2, \mathrm{v} / \mathrm{v})$ and successively partitioned with petrol ether, EtOAc, and $n-\mathrm{BuOH}$. The $\mathrm{BuOH}$ layer was brought to dryness in vacuo to yield $11.8 \mathrm{~g}$ of residue.

Kaempferol 3-O- $\beta$-glucoside 1 (22.4 mg), kaempferol 3-O- $\beta$-rutinoside (nicotiflorin) 2 (9.0 mg), quercetin 3-O- $\beta$-glucoside $3(62.6 \mathrm{mg})$, and luteolin 4 (3.8 $\mathrm{mg}$ ) were isolated from the $\mathrm{BuOH}$ layer of a $\mathrm{MeOH}$ extract of whole plants of $R h$. stellatus by repeated Sephadex $\mathrm{LH}-20$ column chromatography using a mixture of $\mathrm{MeOH},\left(\mathrm{CH}_{3}\right)_{2} \mathrm{CO}$, and $\mathrm{H}_{2} \mathrm{O}(3 / 1 / 1$, v/v/v) as mobile phase. Chlorogenic acid 5 and 3,5-dicaffeoylquinic acid 6 were detected by HPLC/DAD and HPLC/MS in comparison with authentic reference compounds using the methodology described by Fusani and Zidorn in 2010 [13].

NMR spectra were measured at $300 \mathrm{MHz}\left({ }^{1} \mathrm{H} \mathrm{NMR}\right)$ and $75 \mathrm{MHz}\left({ }^{13} \mathrm{C}\right.$ NMR), respectively. Spectra of compounds 1,2 , and 4 were recorded in $\mathrm{CD}_{3} \mathrm{OD}$ and referenced to solvent residual and solvent signals at $3.31 \mathrm{ppm}\left({ }^{1} \mathrm{H}\right.$ NMR) and $49.0 \mathrm{ppm}\left({ }^{13} \mathrm{C}\right.$ NMR), respectively. Spectra of compound 3 were recorded in DMSO- $d_{6}$ and referenced to solvent residual and solvent signals at $2.50 \mathrm{ppm}\left({ }^{1} \mathrm{H} \mathrm{NMR}\right)$ and $39.5 \mathrm{ppm}\left({ }^{13} \mathrm{C} \mathrm{NMR}\right)$, respectively.

\section{Acknowledgement}

The authors thank Sonja Sturm (Institut für Pharmazie, Universität Innsbruck) for mass spectrometric measurements and the Austrian Science Funds (FWF) for a grant to CZ (P20278-B16).

\section{Supporting Information}

A scan of a voucher specimen (Fig. S1) is available in the online version (Format: PDF, Size: ca. 0.6 MB): http://dx.doi.org/10.3797/scipharm.1011-12 


\section{Authors' Statement}

\section{Competing Interests}

The authors declare no conflict of interest.

\section{References}

[1] Enke N, Gemeinholzer B.

Babcock revisited: new insights into generic delimitation and character evolution in Crepis L. (Compositae: Cichorieae) from ITS and matK sequence data.

Taxon. 2008; 57: 756-768.

[2] Sell PD.

Rhagadiolus Scop.

In: Tutin TG, Heywood VH, Burges, NA, Moore DM, Valentine DH, Walters SM, Webb DA (Eds.): Flora Europaea Volume 4.

Cambridge: Cambridge University Press, 1976: 308.

[3] Talavera S.

Rhagadiolus Scop.

In: Valdés B, Talavera S, Fernández-Galiano E (Eds.): Flora Vascular de Andalucia Occidental. Volume 3.

Barcelona: Ketres, 1987: 125.

[4] Rees S, Harborne JB.

Flavonoids and other phenolics of Cichorium and related members of the Lactuceae (Compositae).

Bot J Linn Soc. 1984; 89: 313-319.

doi:10.1111/j.1095-8339.1984.tb02563.x

[5] Markham KR, Ternai B, Stanley R, Geiger H, Mabry TJ.

C-13 NMR studies of flavonoids. 3. Naturally occurring flavonoid glycosides and their acylated derivatives.

Tetrahedron. 1978; 34: 1389-1397.

doi:10.1016/0040-4020(78)88336-7

[6] Scheer T, Wichtl M.

On the occurrence of kaempferol-4-O-beta-D-glucopyranoside in Filipendula ulmaria and Allium cepa.

Planta Med. 1987; 53: 573-574.

doi:10.1055/s-2006-962817

[7] Fuchino H, Nakamura H, Wada H, Hakamatsuka T, Tanaka N.

5-O-glucosylated kaempferols from the fern Dryopteris dickinsii.

Natural Medicines. 1997; 51: 537-538.

[8] Kazuma K, Noda N, Suzuki M.

Malonylated flavonol glycosides from the petals of Clitoria ternatea.

Phytochemistry. 2003; 62: 229-237.

doi:10.1016/S0031-9422(02)00486-7

[9] Zhang L, Luo X, Tian J.

Chemical constituents from Clematis terniflora.

Chem Nat Comp. 2007; 43: 128-131.

doi:10.1007/s10600-007-0061-x

[10] Junior GMV, Sousa CM de M, Cavalheiro AJ, Lago JHG, Chaves MH.

Phenolic derivatives from fruits of Dipteryx lacunifera Ducke and evaluation of their antiradical activities.

Helv Chim Acta. 2008; 91: 2159-2167.

doi:10.1002/hlca.200890233 
[11] Jeong HJ, Ryu YB, Park S-J, Kim JH, Kwon H-J, Kim JH, Park KH, Rho M-C, Lee WS. Neuraminidase inhibitory activities of flavonols from Rhodiola rosea roots and their in vitro antiinfluenza viral activities.

Bioorg Med Chem. 2009; 17: 6816-6823.

doi:10.1016/j.bmc.2009.08.036

[12] Jehle M, Bano J, Ellmerer EP, Zidorn C.

Natural products from Scorzonera aristata (Asteraceae).

Nat Prod Commun. 2010; 5: 725-727.

[13] Fusani P, Zidorn C.

Phenolics and a sesquiterpene lactone in the edible shots of Cicerbita alpina (L.) Wallroth.

J Food Comp Anal. 2010; 23: 658-663.

doi:10.1016/j.jfca.2009.08.014

[14] Sareedenchai V, Zidorn C.

Flavonoids as chemosystematic markers in the tribe Cichorieae of the Asteraceae.

Biochem Syst Ecol. 2010; 38: 935-957.

doi:10.1016/j.bse.2009.09.006

[15] Zidorn C, Schubert B, Stuppner H.

Phenolics as chemosystematic markers in and for the genus Crepis (Asteraceae, Cichorieae).

Sci Pharm. 2008; 76: 743-750.

doi:10.3797/scipharm.0810-25 